U. S. DEPARTMENT OF COMMERCE ROY D. CHAPIN, Secretary

BUREAU OF STANDARDS

LYMAN J. BRIGGS, Acting Director

\title{
GRADING OF
}

\section{SULPHONATED (SULPHATED) OILS SAPONIFIABLE TYPES}

\section{COMMERCIAL STANDARD CS43-32}

\section{[Issued January 26, 1933]}

Effective date for new production Seplember 1, 1932

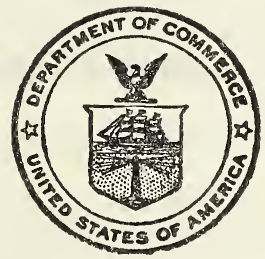

\section{A RECORDED STANDARD OF THE INDUSTRY}

\author{
UNITED STATES
}

GOVERNMENT PRINTING OFFICE

WASHINGTON: 1933

For eale by the Superintendent of Documents, Washington. D. C. - - - Price 5 cents 


\section{PROMULGATION STATEMENT}

At the request of a large user of sulphonated oils, a general conference of representative manufacturers, distributors, and users of sulphonated (sulphated) oils, saponifiable types, on June 30, 1932, adopted Commercial Standard CS43-32 for this commodity. The industry has since accepted and approved for promulgation by the Department of Commerce through the Bureau of Standards the commercial standard as shown herein.

The standard became effective for new production on September $1,1932$.

Promulgation recommended.

Promulgated.

I. J. FAIRChiLd, Chief, Division of Trade Standards.

Promulgation approved.

LYMAN J. BRIGGS, Acting Director, Bureau of Standards.

Roy D. Chapin, Secretary of Commerce. 


\title{
GRADING OF SULPHONATED (SULPHATED) OILS SAPONIFIABLE TYPES
}

\author{
COMMERCIAL STANDARD
}

\section{PURFOSE}

1. This commercial standard is established to provide a basis of understanding for the guidance of producers, distributors, and users, in order to eliminate confusion resulting from a diversity of opinion relative to the grading of sulphonated (sulphated) oil.

\section{SCOPE}

2. This specification covers the method of grading sulphonated (sulphated) oils, saponifiable types, which split off their organically combined $\mathrm{SO}_{3}$ upon boiling with mineral acids, and includes definition, nomenclature, and methods of analysis.

\section{DEFINITION}

3. For the purposes of these specifications, the term "sulphonated oil" shall designate the product of interaction between a saponifiable oil or fat or its fatty acids, or a mixture of saponifiable oils or fats or their fatty acids, and suplhuric acid or similar sulphonating agent, the reaction to take place under such conditions that some or all of the oil is converted into a sulphate. With the exception of water and alkali, it shall contain no other admixture.

\section{NOMENCLATURE}

4. A sulphonated oil of any particular designation shall contain no other oil or fat except the kind designated. For example, an oil sold as sulphonated castor oil shall be manufactured from no other oil or fat except castor oil.

\section{STRENGTH}

5. The strength or concentration of a sulphonated oil shall be expressed as the sum of the percentages by weight of the following active ingredients as determined under "methods of analysis":

(a) Total fatty matter.

(b) Total alkali bound as soap, calculated as $(\mathrm{Na}-1)$.

(c) Neutralized organically combined $\mathrm{SO}_{3}$, calculated as $\left(\mathrm{SO}_{3} \mathrm{Na}-1\right)$.

\section{METHODS OF ANALYSIS}

6. (a) Total fatty matter. - Weigh 5 to $10 \mathrm{~g}$ of the oil into a $500 \mathrm{ml}$ Erlenmeyer flask and add $25 \mathrm{ml}$ of water and $30 \mathrm{ml}$ of concentrated hydrochloric acid. Boil while shaking for about 15 minutes, or until 
the oil and water layers become clear; cool, extract the fat three times with $50 \mathrm{ml}$ portions of ethyl ether, and wash the combined ether layers three times with $10 \mathrm{ml}$ portions of water, or until the wash water is neutral to methyl orange. Evaporate the ether and dry the residue to constant weight at $105^{\circ} \mathrm{C}$. The weight of the dry residue expressed as a percentage of the weight of the oil taken for analysis is the total fatty matter in per cent. ${ }^{1}$

(b) Total alkali bound as soap calculated as $(\mathrm{Na}-1)$.-Weigh $10 \mathrm{~g}$ of the oil into a $250 \mathrm{ml}$ flask, dissolve in $150 \mathrm{ml}$ of water, warming to obtain solution, if necessary. Add $30 \mathrm{~g}$ of granulated sodium chloride, $25 \mathrm{ml}$ of ether, and $5 \mathrm{ml}$ of methyl orange indicator $(0.1$ per cent solution) and titrate with approximately $0.5 \mathrm{~N}$ sulphuric acid. Convert the amount of acid required to its equivalent in milligrams of KOH per gram of sample. Let this value equal $A$.

NoтE.- It is to be noted that when the sulphonated oil contains free alkali special methods of analysis are required.

For the value to be added to other active ingredients, calculate as follows:

$$
\begin{aligned}
A & =\text { milligrams of } \mathrm{KOH} \text { per gram of sample } \\
& =\frac{\mathrm{ml} \mathrm{H}_{2} \mathrm{SO}_{4} \text { required } \times \text { titer of the acid used }}{\text { weight of the sample }}
\end{aligned}
$$

NoтE.-The "titer" of a solution in this standard is the normality equivalent of the solution expressed as the number of milligrams of $\mathrm{KOH}$ per milliliter of the solution.

$$
\text { Per cent combined sodium }=A \frac{(\mathrm{Na}-1)}{56.1 \times 10}=A \times \frac{23-1}{561}=A \times 0.0392
$$

Example.-Let $15.9=$ number of milliliters of sulphuric acid solution required and $28.1=$ titer of this solution.

Then

$$
\text { Per cent combined sodium }=\frac{15.9 \times 28.1 \times 0.0392}{10}=1.75 \text { per cent }
$$

(c) Neutralized organically combined $\mathrm{SO}_{3}$ calculated as $\left(\mathrm{SO}_{3} \mathrm{Na}-1\right)$.(I) Combined $\mathrm{SO}_{3}$ : Weigh $8 \mathrm{~g}$ of the oil into a $300 \mathrm{ml}$ flask and boil for 1 hour under a reflux condenser with $25 \mathrm{ml}$ of normal sulphuric acid, using glass beads to prevent bumping. Shake frequently. Rinse the condenser, disconnect the flask and cool. Add about $20 \mathrm{ml}$ of ether, $100 \mathrm{ml}$ of water, $30 \mathrm{~g}$ of granulated sodium chloride, and $5 \mathrm{ml}$ of methyl orange indicator, 0.1 per cent solution. Titrate with 0.5 $N$ sodium hydroxide. Frequently stopper and shake the flask during the titration. Deduct the equivalent of the added $\mathrm{H}_{2} \mathrm{SO}_{4}$ from the quantity of sodium hydroxide required for the titration and calculate the difference to milligrams of $\mathrm{KOH}$ per gram of sample. Let this value equal $F$.

$$
F=\frac{(\mathrm{ml} \mathrm{NaOH} \text { required } \times \text { titer } \mathrm{NaOH})-\left(25 \times \text { titer } \mathrm{H}_{2} \mathrm{SO}_{4}\right)}{\text { weight of sample }}
$$

1 The "Total fatty matter" obtained in section $6(a)$ is actually too high by 1 hydrogen atom for each "sodium" found in 6(b) and for each " $\mathrm{SO}_{3} \mathrm{Na}^{\circ}$ "group found in $6(c)(2)$. Although the error introduced is small, the atomic weight of hydrogen (1) is introduced into the calculations in $6(b)$ and $6(c)(2)$, in order to have the sum of the active ingredients of the oil, section 5 , correct. 
Then the percentage of combined $\mathrm{SO}_{3}$ equals the sum of $F$ plus $A$, obtained under "total alkali," multiplied by 8 and divided by 56.1 , or per cent combined $\mathrm{SO}_{3}=\frac{(F+A) 8}{56.1}=0.1426(F+A)$.

Example.-

Let $45.5=$ number of $\mathrm{ml}$ of $\mathrm{NaOH}$ required.

$27.6=$ the titer of this $\mathrm{NaOH}$ solution.

$56.3=$ the titer of the sulphuric acid solution used.

For $A$ see calculations under "total alkali."

Then

Per cent combined $\mathrm{SO}_{3}=0.1426 \times\left[\frac{(45.5 \times 27.6)-(25.0 \times 56.3)}{8}\right.$

$$
\left.+\frac{15.9 \times 28.1}{10}\right]=3.67 \text { per cent }
$$

(2) Neutralized organically combined $\mathrm{SO}_{3}$ calculated as $\left(\mathrm{SO}_{3} \mathrm{Na}-1\right)$.-The percentage of neutralized combined $\mathrm{SO}_{3}$, calculated as $\left(\mathrm{SO}_{3} \mathrm{Na}-1\right)$

$=$ Per cent combined $\mathrm{SO}_{3} \times \frac{\mathrm{SO}_{3} \mathrm{Na}-1}{\mathrm{SO}_{3}}$

$=$ Per cent combined $\mathrm{SO}_{3} \times \frac{102}{80}$

$=$ Per cent combined $\mathrm{SO}_{3} \times 1.275$

Example.-Neutralized combined $\mathrm{SO}_{3}$ equals $1.275 \times 3.67=4.68$ per cent.

\section{HISTORY OF PROJECT}

On April 3, 1931, a large user of sulphonated oil requested the cooperation of the Bureau of Standards in the establishment of a commercial standard for that product.

Upon investigation, the bureau found that there was a real demand for such a standard and that the industry would be glad to cooperate in the undertaking. Therefore, Ralph Hart, of the Hart Products Corporation, in collaboration with I. Silverman and R. Wexler prepared a tentative draft of a proposed specification which was discussed at a manufacturers' preliminary conference in New York on November 24, 1931.

This conference was unable to agree on the proposed specification and invited C. P. Gulick, Ralph Hart, I. Silverman, William Seltzer, and $\mathrm{E}$. I. Rice to prepare a specification for consideration at a future meeting.

Accordingly, on April 28, 1932, the manufacturers met and approved their committee's specification with the request that it be considered by a general conference representing the entire industry.

Agreeable to this request a general conference of manufacturers, distributors, and users of sulphonated oils met on June 30, 1932, and adopted the specification with the recommendation that it be circulated to the industry for approval.

The conference approved application of the certification plan, which provides for the listing of those companies who are willing to certify that the grading of their sulphonated oils conforms to the requirements of this commercial standard. 
The standard became effective on September 1, 1932, with the understanding that it be considered by the standing committee for revision once yearly.

The conference elected the following standing committee:

Mianufacturers:

RALPH HART (chairman), treasurer, Hart Products Corporation, New York, N. Y.

I. Silverman, I. Sonneborn Sons (Inc.), Belleville, N. J.

Grorge W. Aspey, Jacques-Wolf Co., Passaic, N. J. Distributors:

C. P. Gulick, National Oil Products Co., Harrison, N. J.

J. L. Schroeder, vice president, A. Klipstein \& Co. (Inc.), New York, N. Y. Users:

C. L. Schutria, sales manager, John Campbell \& Co., New York, N. Y.

Hill Hunter, Proximity Manufacturing Co., Greensboro, N. C.

P. J. Wood, Apex Oriental Corporation, Haledon, N. J.

Hugh Christenson, Arlington Mills, Lawrence, Mass. 


\section{ACCEPTANCE OF COMMERCIAL STANDARD}

(This sheet properly filled in, signed, and mailed to the addiess indicated will provide for the recording of your organization as an acceptor of the commercial standard)

$$
\text { Date }
$$

\section{Division of Trade Standards, Bureau of Standards, Washington, D. C.}

Gentlemen: Having considered the statements on the reverse of this sheet we hereby record our acceptance of the commercial standard as our standard practice in the production, ${ }^{1}$ distribution, ${ }^{1}$ use ${ }^{1}$ of standard grading of sulphonated (sulphated) oils, saponifiable types, for one year beginning (Date) revised.

Realizing that the value of any commercial standard - depends upon the amount of active support it receives, we aill use such effort as may be appropriate to secure additional adherence whenever the opportunity offers.

I Furthermore, we plan to cooperate with the standing committee in every reasonable way to assist it in the intelligent consideration of constructive revisions to be presented for adoption in accordance with established commercial standards procedure.

Signature

(A bove signature should be in ink)

(Kindly typewrite or print the following lines)

Title

Company -

Street address

City and State

1 Please designate which group you represent by drawing lines through the other two. In the case of related interests, trade papers, colleges, etc., desiring to record their general approval, the words "In principle" should be added after the signature. 


\section{TO THE ACCEPTOR}

The following information is given in answer to the usual questions arising in connection with the acceptance form:

1. Commercial standards are commodity specifications voluntarily established by mutual consent of the industry. They present a common basis of understanding between the producer, distributor, and consumer and should not be confused with any plan of governmental regulation or control. The Department of Commerce has no regulatory power in the enforcement of their provisions, but since they represent the will of the industry as a whole, their provisions through usage soon become established as trade customs.

2. The acceptor's responsibility. - The purpose of commercial standards is to establish for specific commodities nationally recognized grades or consumer criteria and the benefits therefrom will be measurable in direct proportion to their general recognition and actual use. Instances will occur when it may be necessary to deviate from the standard and the signing of an acceptance does not preclude such departures; however, such signature indicates an intention to follow the commercial standard where practicable, in the production, distribution, or consumption of the article in question.

3. The department's responsibility. - The function performed by the Department of Commerce in the establishment of a commercial standard is fourfold; first, to act as an unbiased coordinator to bring all branches of the industry together for the mutually satisfactory adjustment of trade standards; second, to supply such assistance and advice as past experience with similar programs may suggest; third, to canvass and record the extent of acceptance and adherence to the standard; and fourth, to add all possible prestige to the enterprise by publication and promulgation when accepted by the industry.

When the standard has been endorsed by companies representing a satisfactory majority of production, the success of the project is announced. If, however, in the opinion of the standing committee of the industry or the Department of Commerce, the support of any standard is inadequate, the right is reserved to withhold promulgation and publication. 


\section{ACCEPTORS}

\section{ASSOCIATIONS}

Better Fabrics Testing Bureau, New York, N. Y.

Laundryowners National Association of the United States and Canada, Joliet, Ill.

National Association Institute of Dyeing and Cleaning (Inc.), Silver Spring, Md.

National Association of Wool Manufacturers, Boston, Mass.

Sulphonated Oil Manufacturers Association, New York, N. Y. (in principle).

\section{FIRMS}

Aberfoyle Manufacturing Co., Chester, $\mathrm{Pa}$.

Acadia Mills, Boston, Mass.

Alabama Polytechnic Institute, School of Textile Engineering, Auburn, Ala. (in principle).

Althouse Chemical Co., Reading, Pa. (in principle).

American Aniline \& Extract Co. (Inc.), Philadelphia, $\mathrm{Pa}$.

American Felt Co., New York, N. Y.

American Finishing Co., Memphis, Tenn.

American Mills Co., The, Waterbury, Conn.

American Review of Shoes \& Leather, Philadelphia, $\mathrm{Pa}$. (in principle).

American Silk \& Rayon Journal, New York, N. Y. (in principle).

American Woolen Co., New York, N. Y.

Anchor Color \& Gum Works, Dighton, Mass.

Apex Chemical Co. (Inc.), New York, N. Y.

Apex Oriental Corporation, Paterson, N. J.

Arkansas Co. (Inc.), New York, N. Y. Arnold, Hoffman \& Co. (Inc.), Providence, R. I.

Arabol Manufacturing Co., The, New York, N. Y.

Asheville Cotton Mills, Asheville, N. C. Associated Dyeing \& Printing Co. (Inc.), Paterson, N. J.

Avondale Mills, Birmingham, Ala.

Barre Wool Combing Co. (Ltd.), The, South Barre, Mass.

Belmar Dye Works (Inc.), Astoria, L. I., N. Y.

Berg Laboratories, Charles W., Philadelphia, Pa.
Bernat \& Sons Co., Emile, Jamaica Plain, Mass.

Bigelow-Sanford Carpet Co., Amsterdam, N. Y.

Bigelow-Sanford Carpet Co. (Inc.), Thompsonville, Conn.

Blumenthal \& Co. (Inc.), Sidney, Shelton, Conn.

Borden \& Remington Co., Fall River, Mass. (in principle).

Botany Worsted Mills, Passaic, N. J.

Bradford Cotton Mills, Prattville, Ala.

Bradford Dyeing Association, Bradford, R. I.

Broadalbin Knitting Co. (Ltd.), The, Braodalbin, N. Y.

Burkart-Schier Chemical Co., Chattanooga, Tenn.

Burns Co., W. H., Frankford, Philadelphia, $\mathrm{Pa}$.

Callaway Mills, La Grange, Ga.

Campbell \& Co., John, New York, N. Y.

Carbic Color \& Chemical Co. (Inc.), New York, N. Y.

Charlton Woolen Co., Chariton City, Mass.

Ciba Co. (Inc.), New York, N. Y.

Clark Thread Co., The, Bloomfield, N. J.

Clemson A. \& M. College, textile department, Clemson College, S. C.

Cliffside Mills, Cliffside, N. C.

Columbia Mills (Inc.), The, Minetto, N. Y.

Conestogo Cotton Mills (Inc.), Lancaster, $\mathrm{Pa}$.

Corn Products Refining Co., New York, N. Y. (in principle).

Cramerton Mills (Inc.), Cramerton, N. C.

Dacotah Cotton Mills, Lexington, N. C. Dennis Co., The Martin, Newark, N. J.

Delta Finishing Co., Philadelphia, Pa.

Diamond Braiding Mills, Chicago Heights, III.

Ducas Co. (Inc.), B. P., New York, N. Y.

DuPont de Nemours \& Co., F. I., Chicago, Ill.

Dyestufis Corporation of America, Boston, Mass.

Eagle \& Co. (Inc.), C. K., Shamokin, $\mathrm{Pa}$.

Ecclestone Chemical Co., The, Detroit, Mich.

Eno Cotton Mills, Hillsboro, N. C.

Ericksen Textile Co., Momence, IIl. 
Esselen, jr., Gustavus J., Boston, Mass. Farr Alpacea Mill No. 2, Holyoke, Mass.

Forstmann \& Co., Julius, Passaic, N. J.

Franklin Oil \& Gas Co, The, Bedford, Ohio.

French Textile School, A., Atlanta, Ga. (in principle).

Fulton Dye \& Import Co. (Inc.), New York, N. Y.

Gotham Silk Hosiery Co. (Inc.), Wharton, N. J.

Granite Finishing Works, Haw River, N. C.

Great Lakes Thread \& Yarn Co., Detroit, Mich.

Greenville Finishing Co. (Inc.), Greenville, R. I.

Guerin Mills (Inc.), (Posemont Mill), Woonsocket, R. I.

Hart Products Corporation, The, New York, N. Y.

Haynes Mills (Inc.), Clifiside, N. C.

Hellwig Silk Dyeing Co., Philadelphia, $\mathrm{Pa}$.

Herrick-Voight Chemical Corporation, Bayonne, N. J.

Hochstadter Laboratories (Inc.), New York, N. Y. (in principle).

Hubbard Drycleaning \& Redyeing School, Silver Spring, Md. (in principle).

Jordan, jr., Manufacturing Co., W. H. \& F., Philadelphia, Pa.

Kali Manufacturing Co., Philadelphia, $\mathrm{Pa}$.

Kem Products Co. (Inc.), Newark, N.J.

Klipstein \& Co. (Inc.), A., New York, N. Y.

Laurel Soap Manufacturing Co. (Inc.), Philadelphia, $\mathrm{Pa}$.

Lavonia Manufacturing Co., Lavonia, Ga.

Lawrason \& Co. (Ltd.), S. F., London, Ontario, Canada.

Leomar Processing Corporation, Providence, R. I.

Linder \& Co. (Inc.), Brighton, Mass.

Lowell Bleachery South, Griffin, Ga.

Lowell Textile Institute, Lowell, Mass.

Mansure Co., E. L., Chicago, Ill.

Manufacturers Soap \& Chemical Co., Cleveland, Tenn.

Marden-Wild Corporation, Somerville, Mass.

McClellan \& Son, Chas. P., Fall River, Mass.

Mellon Institute, Pittsburgh, Pa.

Meyer Thread Co., John C., Lowell, Mass

Michigan State College, East Lansing, Mich. (in principle).

Minneola Manufacturing Co., Gibsonville, N. C.

Montgomery Co., Windsor Locks, Conn.

Monument Mills, Housatonic, Mass.
National Oil Products Co., Harrison, N. J.

Neutrasol Products Corporation, Jersey City, N. J.

North Carolina Finıshing Co., Salisbury, N. C.

North Carolina State College Textile School, Raleigh, N. C. (in principle).

Nyanza Color \& Chemical Co. (Inc.), New York, N. Y.

Onyx Oil \& Chemical Co., Jersey City, N. J.

Pacific Mills, Boston, Mass.

Pacific Milıs, worsted division, Lawrence, Mass.

Pan-American Research Laboratories, New York, N. Y. (in principle).

Passaic Print Works, Passiac, N. J.

Penn Worsted Co., Philadelphia, Pa.

Pepperell Manufacturing Co., Biddeford, Me.

Pepperell Manufacturing Co., Boston, Mass.

Perkins Soap Co., Springfield, Mass.

Piedmont Processing Co., Belmont, N. C.

Powdrell \& Alexander (Inc.), Danielson, Conn.

Providence Drysalters Co., Providence, R. I.

Providence Dyeing, Bleaching \& Calendering Co., Providence, R. I.

Proximity Cotton Mills, Greensboro, N. C.

Proximity Manufacturing Co., Greensboro, N. C.

Proximity Print Works, Greensboro, N. C.

Quidnick Dyeworks, Quidnick, R. I.

Rayonite Co. (Inc.), Tacouy, Philadelphia, Pa.

Rayon Publishing Corporation, New York, N. Y. (in principle).

Reilly-Whiteman-Walton Co., Conshohocken, Pa.

Renfrew Bleachery, Travelers Rest, S. C.

Revolution Cotton Mills, Greensboro, N. C.

Richards Chemical Works (Inc.), The, Jersey City, N. J.

Riverside \& Dan River Cotton Mills (Inc.), Danville, Va.

Roanoke Mills Co., Roanoke Rapids, N. C.

Rosemary Manufacturing Co., Roanoke Rapids, N. C.

Royce Chemical Co., Carlton Hill, N. J.

Sagamore Color \& Chemical Co., Boston, Mass.

Salem Oil \& Grease Co., Salem, Mass.

Salisbury Cotton Mills, Salisbury, N. C.

Sandoz Chemical Works (Inc.), New York, N. Y. (in principle).

Scholler Bros. (Inc.), Philadelphia, Pa. 
Seacoast Laboratories (Inc.), New York, N. Y.

Seamans \& Cobb Co., Hopkins, Mass. Searell, George W., New Bedford, Mass.

Seydel Chemical Co., Jersey City, N. J.

Seydel-Woolley Co., Atlanta, Ga.

Shaw \& Co. (Inc.), John, Boston, Mass.

Silk Grading \& Testing Laboratory (Inc.), New York, N. Y.

Slack Corporation, John T., Springfield, Vt.

Sonneborn Sons (Inc.), L., New York, N. Y.

South Dakota State College, Brookings, S. Dak. (in principle).

Spalding Knitting Mills, Griffin, Ga.

Standard Bleachery \& Printing Co., The, Carlton Hill, N. J.

Statesville Cotton Mills, Statesville, N. C.

Stein Hall \& Co. (Inc.), New York, N. Y. (in principle).

Stone, Charles H., Charlotte, N. C.

Summerville Cotton Mills, Summerville, Ga.

Sunbury Converting Works, Sunbury, Pa.

Tabardrey Manufacturing Co., Haw River, N. C.

Textile Products Co., Providence, R. I. Tubize Chatillon Corporation, Rome, Ga.

Union Bleachery, Greenville, S. C.
United Plece Dye Works, The, Lodi, N. J.

U. S. Appraisers' Laboratory, New York, N. Y.

U. S. Oil Co., Providence, R. I.

United States Testing Co. (Inc.), Hoboken, N. J. (in principle).

Waite Carpet Co., Oshkosh, Wis.

Waynesboro Knitting Co., Waynesboro, $\mathrm{Pa}$.

White, Noel D., Signal Mountain, Tenn.

White \& Bagley Co., The, Worcester, Mass.

White \& Hodges, Everett, Mass.

White Oak Cotton Mills, Greensboro, N. C.

Whittenton Manufacturing Co. (Inc.), Taunton, Mass.

Woburn Degreasing Co. of New Jersey, Harrison, N. J.

Wolf \& Co., Jacques, Passaic, N. J.

Young \& Co., Charles W., Philadelphia, $\mathrm{Pa}$.

GOVERNMENT

District of Columbia, Government of, Purchasing Office, Washington, D. C'. Metropolitan police department, Washington, D. C. (in principle).

United States Department of the Interior, Washington, D. C.

Treasury Department, Washington, D. C.

Veterans' Administration, procurement division, Washington, D. C. 


\section{COMMERCIAL STANDARDS}

CS No.

0-30. The commercial standards service and its value to business.

1-32. Clinical thermometers (second edition).

2-30. Mopsticks.

3-28. Stoddard solvent.

4-29. Staple porcelain (all-clay) plumbing fixtures.

5-29 "Steel pipe nipples.

6-31. Wrought iron pipe nipples (second edition)

7-29. Standard weight malleable iron or steel screwed unions.

8-30. Plain and thread plug and ring gage blanks.

9-29. Builders' template hardware.

10-29. Brass pipe nipples.

11-29. Regain of mercerized cotton yarns.

12-29. Domestic and industrial fuel oils.

13-30. Dress patterns.

14-31. Boys' blouses, button-on waists, shirts, and junior shirts.

15-29. Men's pajamas.

16-29. Wall paper.

17-32. Diamond-core drill fittings (second edition).

18-29. Hickory golf shafts.

19-30. Foundry patterns of wood.

20-30. Staple vitreous china plumbing fixtures.

21-30. Interchangeable ground glass joints.

22-30. Builders' hardware (nontemplate).

NoтісE.-Those interested in commercial standards with a view toward accepting them as a basis of everyday practice in their industry, may secure copies of the above standards, while the supply lasts, by addressing the Division of Trade Standards, Bureau of Standards, Washington, D. C.
CS No. Item

Standard screw threads.

5-30. Special screw threads.

26-30. Aromatic red-cedar closet lining.

27-30. Plate-glass mirrors.

28-32. Cotton-fabric tents, tarpaulins, and covers.

29-31. Staple seats for water-closet bowls.

30-31. Colors for sanitary ware.

31-31. Red-cedar shingles. coating.

34-31. Bag, case, and strap leather.

35-31. Plywood (hardwood and eastern red cedar).

36-31. Fourdrinier wire cloth.

37-31. Steel bone plates and screws.

38-32. Hospital rubber sheeting.

39-32. Wool and part wool blankets.

40-32. Surgeons' rubber gloves.

41-32. Surgeons' latex gloves.

42-32. Fiber insulating board.

43-32. Grading of sulphonated (sulphated) oils, saponifiable types.

44-32. A pple wraps (in preparation).

45-33. Douglas fir plywood (in preparation).
23-30. Feldspar.

32-31. Cotton cloth for rubber and pyroxylin

33-32. Knit underwear (exclusive of rayon). 